\title{
CCR3 Blockade Attenuates Eosinophilic lleitis and Associated Remodeling
}

\author{
Joanne C. Masterson, ${ }^{\star \dagger \ddagger \S}$ Eóin N. McNamee, ${ }^{+\S \uparrow}$ \\ Paul Jedlicka, ${ }^{\|}$Sophie Fillon, ${ }^{* \dagger \ddagger \S}$ \\ Joseph Ruybal, ${ }^{* \dagger \ddagger \S}$ Lindsay Hosford, ${ }^{* \dagger \ddagger \S}$ \\ Jesús Rivera-Nieves, ${ }^{\ddagger 1 \S}$ James J. Lee, ${ }^{* *}$ and \\ Glenn T. Furuta*†‡§ \\ From the Section of Pediatric Gastroenterology, Hepatology and \\ Nutrition-Digestive Health Institute, and the Gastrointestinal \\ Eosinophilic Diseases Program, ${ }^{\dagger}$ Children's Hospital Colorado, \\ Aurora, Colorado; the Mucosal Inflammation Program, ${ }^{\ddagger}$ Division \\ of Gastroenterology, "Department of Pathology, and the \\ University of Colorado Denver School of Medicine, ${ }^{\S}$ Aurora, \\ Colorado; and the Department of Biochemistry and Molecular \\ Biology,** Mayo Clinic, Scottsdale, Arizona
}

Intestinal remodeling and stricture formation is a complication of inflammatory bowel disease (IBD) that often requires surgical intervention. Although eosinophils are associated with mucosal remodeling in other organs and are increased in IBD tissues, their role in IBD-associated remodeling is unclear. Histological and molecular features of ileitis and remodeling were assessed using immunohistochemical, histomorphometric, flow cytometric, and molecular analysis (real-time RT-PCR) techniques in a murine model of chronic eosinophilic ileitis. Collagen protein was assessed by Sircol assay. Using a spontaneous eosinophilic Crohn's-like mouse model SAMP1/SkuSlc, we demonstrate an association between ileitis progression and remodeling over the course of 40 weeks. Mucosal and submucosal eosinophilia increased over the time course and correlated with increased histological inflammatory indices. Ileitis and remodeling increased over the 40 weeks, as did expression of fibronectin. CCR3-specific antibody-mediated reduction of eosinophils resulted in significant decrease in goblet cell hyperplasia, muscularis propria hypertrophy, villus blunting, and expression of inflammatory and remodeling genes, including fibronectin. Cellularity of local mesenteric lymph nodes, including T- and B-lymphocytes, was also significantly reduced. Thus, eosinophils participate in intestinal remodeling, supporting eosinophils as a novel therapeutic target. (Am J Pathol 2011, 179:2302-2314; DOI: 10.1016/j.ajpath.2011.07.039)
Intestinal remodeling is a complex process that in health results in mucosal healing and in disease leads to pathological consequences that include stricture formation. Stricture formation is a common complication of inflammatory bowel disease (IBD), occurring in up to $30 \%$ of patients with Crohn's disease and occasionally in ulcerative colitis. ${ }^{1}$ Although current therapeutic strategies address inflammation, treatment of strictures most frequently involves surgical resection. ${ }^{2}$

Inflammatory bowel disease has traditionally been associated with lymphocytes, NKT cells, dendritic cells, macrophages, and neutrophils, ${ }^{3}$ but a growing body of evidence supports functional roles also for eosinophils in IBD. ${ }^{4-6}$ To date, clinical evidence demonstrating the importance of eosinophils in IBD has been limited to histological analysis and peripheral biomarker measurements. Lampinen et $\mathrm{al}^{7}$ reported that eosinophil numbers were increased in active disease, compared with normal control subjects. Other studies documented evidence of eosinophilia in IBD with increased numbers of eosinophils and eosinophil products in the mucosa and stool of patients with IBD. ${ }^{5,7-9}$ Although eosinophils are increased during inflammation in $\mathrm{IBD},{ }^{5}$ a clear role for them in the pathogenesis of IBD has not been elucidated.

Murine studies have defined a role for eosinophils in acute colonic inflammation. ${ }^{8,10,11}$ The strongest evidence supporting a pathogenic role for eosinophils in intestinal remodeling measured acute inflammation in the murine dextran sulfate sodium (DSS) colitis model. Forbes et al ${ }^{12}$ demonstrated that eosinophil peroxidase (EPO)-null mice were protected from 8 days of DSS colitis. Similarly, Shichijo et $\mathrm{al}^{13}$ identified a key role for another eosinophil granule protein, eosinophil cationic protein (ECP), in

Supported by NIH grants R01-DK62245 (G.T.F.) and R01-DK 08021201 A2 (J.R.N.), by the Pappas Foundation (G.T.F.), by Crohn's \& Colitis Foundation Research Fellowship Award no. 3047 (J.M.), and NIH/NCRR Colorado CTSI grant UL1 RR025780 (J.M. and G.T.F.).

Accepted for publication July 26, 2011

Supplemental material for this article can be found at http://ajp. amjpathol.org or at doi: 10.1016/j.ajpath.2011.07.039.

Address reprint requests to Glenn T. Furuta, M.D., Department of Pediatrics, University of Colorado Denver, School of Medicine, 13123 East 16th Ave, B290, Aurora, CO 80045. E-mail: glenn.furuta@ childrenscolorado.org 
acute colitis. Our previous work highlighted a significant role for major basic protein (MBP) in intestinal epithelial barrier disruption after 7 days of colonic inflammation. ${ }^{14}$ Eosinophil-null mice (PHIL and $\Delta$ dbIGATA) are relatively protected from DSS colitis, compared with wild-type controls, ${ }^{8,11}$ providing strong evidence for the participation of eosinophils in the early stages of intestinal inflammation. Finally, in a study transmitting ileitis via adoptive transfer of $\mathrm{CD} 4^{+} \mathrm{T}$ cells from Th1-cytokine-driven SAMP1/Yit mice into immunodeficient SCID mice injected therapeutically with antibody to the critical eosinophilopoietin IL-5, Takedatsu et al ${ }^{15}$ showed improved ileo-colonic inflammation. In that study, the contribution of eosinophils to remodeling was not addressed; however, the authors provided evidence for the importance of eosinophils in mediating the initiation of ileal inflammation in this adoptive transfer system. To date, no other study has directly addressed the role of eosinophils in chronic inflammation and remodeling in vivo.

IBD-associated fibrosis is a multifactorial process, ${ }^{1,6}$ and although animal models indicate a role for eosinophils in acute colonic inflammation, little is known regarding the role of eosinophils in chronic ongoing ileitis or in intestinal remodeling, such as is found in patients with Crohn's disease. In this regard, eosinophils remain sources of mediators associated with fibrosis and are commonly detected in inflamed and fibrotic tissues in diseases at other sites, as well as in the gastrointestinal tract. ${ }^{16}$ Eosinophils secrete a number of profibrotic mediators, including members of the transforming growth factor-beta family (TGF- $\beta$ s), fibroblast growth factors, matrix metallopeptidases (MMPs), and profibrotic cytokines (including IL-13). ${ }^{17,18}$ Targeted reduction of eosinophils in patients with asthma reduces pulmonary remodeling. ${ }^{19}$ Patients with eosinophilic esophagitis can develop esophageal strictures and remodeling. ${ }^{17,20}$

On the basis of these observations, we hypothesized that eosinophilic inflammation contributes to ileal remodeling. To date, no other study has directly addressed the role of eosinophils in chronic spontaneous inflammation and remodeling in vivo. Because very few mouse models of chronic spontaneous IBD exist, we performed a 40week longitudinal study defining the characteristics of remodeling in the original Th2-SAMP1 mouse model of chronic ileitis. Our data suggest that eosinophils play a role in ileal remodeling and that in patients with IBD the therapeutic targeting of eosinophils may lead to reductions in remodeling events that lead to stricture formation, which subsequently requires surgery.

\section{Materials and Methods}

\section{Mice}

Original SAMP1 strain SAMP1/SkuSIc ${ }^{21}$ female mice 4 to 10 weeks of age were purchased from Japan SLC (Hamamatsu, Japan). SAMP1 mice were derived from brother-sister mating of AKR/J mice. AKR mice (AKR/J; a/a Tyr ${ }^{C} /$ Tyr $^{c}$ Soat ${ }^{\text {ald }} /$ Soat ${ }^{\text {ald }}$ hid/hid), which have been described previously, ${ }^{22}$ were purchased from the Jack- son Laboratory (Bar Harbor, ME) and served as noninflamed controls. Mice were maintained under specific pathogen-free conditions with ad libitum access to food and water. Mouse studies were approved by the University of Colorado Denver Institutional Animal Care and Use Committee.

\section{Intestinal Permeability Assay}

For assessment of intestinal permeability, mice were orally gavaged with a solution of $80 \mathrm{mg} / \mathrm{mL}$ fluorescein isothiocyanate (FITC)-labeled dextran (4 kDa; Sigma-Aldrich, St Louis, MO) as described previously. ${ }^{23}$ Mice were sacrificed 4.5 hours after administration and whole blood was collected. Serum was isolated and placed in triplicate into a 96-well plate. Presence of FITC-dextran was assessed by fluorometric techniques and was quantified against a standard curve of FITC-labeled dextran.

\section{Dexamethasone Treatment}

For dexamethasone treatment studies, mice were injected intraperitoneally with $100 \mu \mathrm{g}$ dexamethasone (Vedco, St. Joseph, MO) in a volume of $200 \mu \mathrm{L}$ every second day from 20 weeks of age for 10 days. ${ }^{10}$ Control mice were injected intraperitoneally with an equal volume of saline at equal frequency and duration.

\section{Anti-CCR3 Treatment}

Anti-CCR3 rat anti-mouse monoclonal antibody 6S2-19-4 selectively depletes murine eosinophils. ${ }^{24,25}$ This antibody has been shown to selectively target cells with sufficient density of receptor on their surface for complement mediated cell lysis. ${ }^{25,26}$ For antibody inhibition studies, mice were injected intraperitoneally with $200 \mu \mathrm{g}$ of anti-CCR3 antibody once weekly from 20 to 30 weeks of age. Inflamed controls mice were injected intraperitoneally with a nonspecific isotype control antibody for equal duration. Mice were sacrificed 24 hours after final treatments.

\section{Tissue Collection and Histological and Morphometric Analysis}

Terminal ileal tissue was removed and fixed with 10\% neutral buffered formalin, processed, embedded in paraffin, and cut into $5-\mu \mathrm{m}$ sections. Resulting sections were stained with H\&E (Sigma-Aldrich) according to the manufacturer's specifications, and a global inflammatory score based on a quantitative index was assigned by a pathologist blinded to the experimental conditions (P.J.), as described previously. ${ }^{10,23}$ Briefly, three histological parameters were assessed, with equal weight given to each parameter: i) active inflammation (granulocyte infiltration, including neutrophils and eosinophils), ii) chronic inflammation (lymphoplasmacytic infiltration), and iii) villus distortion (architectural disorder and separation of villi, crypts, and muscularis propria). To assess goblet cell hyperplasia, ileal sections were stained with PAS and 
counterstained with hematoxylin. Goblet cells were counted and reported as a percentage of total villus epithelial cells. Seven random high-power fields per mouse were assessed for muscularis propria width, villus and crypt length, and goblet cell numbers. A minimum of 21 measurements were made per intestinal section. The most sensitive and accurate way to assess infiltrating eosinophils is by eosinophil granule-specific immunostaining; here, we used a rat anti-mouse MBP monoclonal as described previously. ${ }^{10}$ Sections were deparaffinized, quenched of endogenous peroxidase, blocked with normal serum, and incubated with rat anti-mouse MBP1 antibody (clone MT-14.7). Slides were washed and incubated with biotinylated anti-rat antibody and avidin-biotin complex $(A B C)$ or avidin-biotin complex alkaline phosphatase (ABC-AP). All steps were performed while blocking endogenous biotin/avidin. Slides were developed either by nickel diaminobenzidine, enhanced with cobalt chloride or with permanent red substrate and counterstained with Methyl Green. Eosinophils were quantified by standard area measurement to obtain the number of eosinophils per high-power field, as described previously. ${ }^{10}$

\section{Cell Isolation and Flow Cytometric Analysis}

Splenocytes, mesenteric lymph nodes (MLN), and ileum lamina propria (LP) mononuclear cells were isolated as described previously. ${ }^{10} \mathrm{Fc} \gamma$ receptor blockade was performed with CD16/32 (no. 93; eBioscience, San Diego, CA). Cells from indicated compartments were surfacestained with fluorescently labeled antibodies directed against IL-5R $\alpha$-FITC (T21), CCR3-AF647 (83103), SiglecF-PE (E50-2440) (BD Biosciences, San Jose, CA), CD4-APC-Cy7 (GK1.5; BioLegend, San Diego, CA), and CD8-eFluor450 (Ly-2), CD62L-PeCy7 (MEL-14), CD44FITC (IM7) (eBioscience), or corresponding isotype controls. Fluorescence analysis was performed using a BD FACSCanto II flow cytometer (BD Biosciences). Data files were further analyzed using FlowJo software version 8.7 (Tree Star, Ashland, OR).

\section{RNA and Real-Time Reverse Transcription Polymerase Chain Reaction}

Total RNA was prepared using an RNeasy mini kit (Qiagen, Valencia, CA), as described previously. For all gene transcripts assessed, first-strand cDNA synthesis was performed from 500 ng of total RNA using a high-capacity cDNA archive kit (Applied BioSystems, Foster City, CA). Transcript expression was assessed using TaqMan gene expression assays with TaqMan probes (Applied Biosystems). RT-PCR reactions were performed with $A B$ solute Blue QPCR ROX mix (Thermo Scientific, Surrey, UK), cDNA, and TaqMan assay mixtures. Thermocycling and subsequent analysis were performed with an $A B I$ 7300 real-time PCR instrument and $A B I R Q$ software version 1.4.4. Data were normalized to $18 \mathrm{~S}$ expression and were calculated for each sample as relative quantity $R Q$ $=2^{-\Delta \Delta C t}$, where $\mathrm{Ct}$ is the cycle threshold. $\mathrm{RQ}$ values are presented as fold change in mRNA expression relative to controls.

\section{Sircol Collagen Assay}

lleal collagen content was measured using a Sircol assay kit (Biocolor, Carrickfergus, Northern Ireland, UK) according to the manufacturer's recommendations. Whole ileal tissues were homogenized in tissue lysis buffer (PBS) containing protease inhibitors (Roche Applied Science, Indianapolis, IN) and phosphatase inhibitors (Sigma-Aldrich). Total protein concentration was determined using the Bradford assay, with bovine serum albumin as standard. Results are reported as nanograms of total collagen per microgram of total ileal protein.

\section{Statistical Analysis}

Statistical analyses of data outcomes were performed using a two-tailed Student's t-test. Data are expressed as means \pm SEM. Pearson's correlation coefficient was used to determine the relationship between eosinophil number and histological measures of ileitis. A $P$ value of $<0.05$ was used to determine statistical significance.

\section{Results}

\section{Severity of lleitis Correlates with Ileal Eosinophilia}

To determine whether eosinophilic inflammation was associated with inflammation and remodeling, intestinal eosinophilia was measured in ileal tissues over the 40-week time course. At 5 weeks of age, the ileal mucosa of SAMP1 mice revealed no inflammation, similar to control mice of the same age; SAMP1 mice also contained a similar number of eosinophils as observed in uninflamed controls (data not shown). Immunohistochemical staining of tissues for MBP identified eosinophils predominantly in the ileal mucosal and submucosal regions, with some eosinophils infiltrating the muscular and serosal layers (Figure 1A). Between 10 and 40 weeks of age, mice developed progressive, transmural ileal inflammation ${ }^{10}$ consisting of mononuclear cells as well as eosinophils (Figure 1B). This eosinophilic inflammation and remodeling developed between 5 and 10 weeks of age; analysis of 8-week-old mouse ilea from SAMP1 mice demonstrated early progression of eosinophilia, inflammation, and remodeling (data not shown). Eosinophil number correlation with global histological inflammatory index was performed at 5, 10, and 40 weeks of age; $(r=0.92$; $P<0.05)$ (Figure 1C). Cytokines and receptors associated with eosinophilia (ie, CCL11, CCL24, and CCR3) increased during the time course, relative to agematched controls (Figure 1D).

Further characterization of ileal lamina propria eosinophil population was performed by flow cytometry. Gating on the entire granulocyte forward scatter/side scatter population demonstrated a significant increase in granulocytes in ileal lamina propria by 14 weeks of age 
A
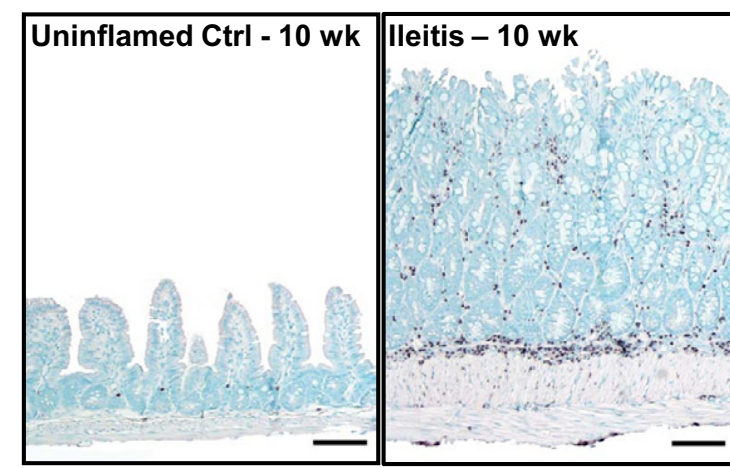

B

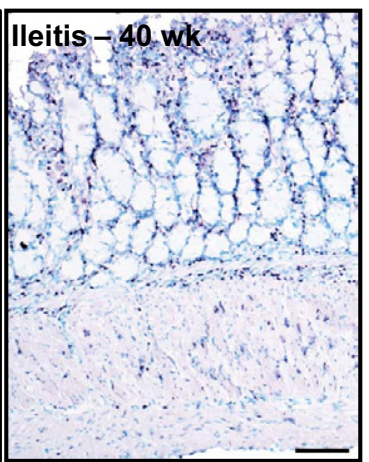

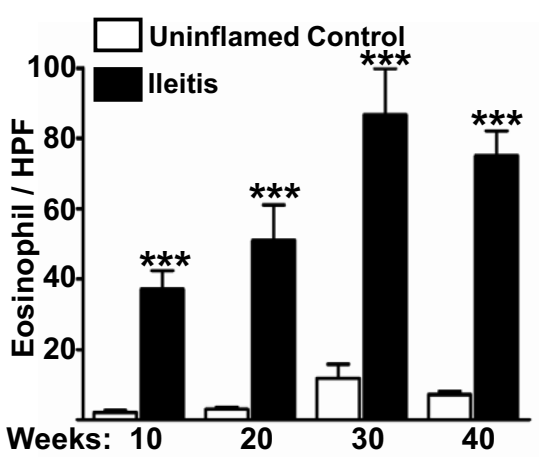

C

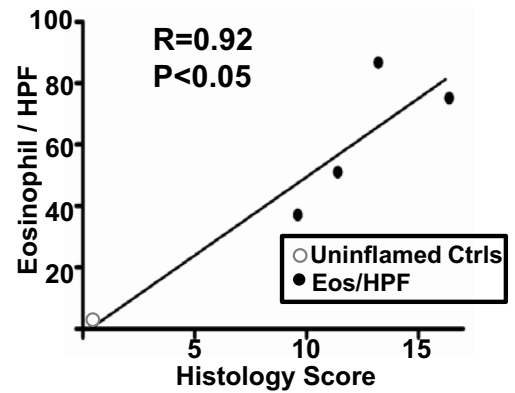

$\mathrm{D}$

\begin{tabular}{|lllll|}
\hline Ileitis & & & & \\
\hline GENE & 10 Weeks & 20 Weeks & 30 Weeks & 40 Weeks \\
\hline CCL11 & $1.2 \pm 0.2$ & $2.4 \pm 0.1^{* * *}$ & $4.4 \pm 0.7^{* * *}$ & $6.0 \pm 0.5^{* *}$ \\
CCL24 & $1.9 \pm 0.7$ & $6.0 \pm 0.6^{* * *}$ & $6.7 \pm 2.2^{*}$ & $7.3 \pm 1.5^{*}$ \\
CCR3 & $6.7 \pm 2.1^{*}$ & $8.4 \pm 0.4^{* * *}$ & $19.6 \pm 5.0^{* * *}$ & $13.5 \pm 1.4^{* *}$ \\
\hline
\end{tabular}

Figure 1. Eosinophilic inflammation in chronic eosinophilic ileitis. A: Representative major basic protein (MBP) immunostained ileal tissue. Scale bars $=100 \mu \mathrm{m}$. B: Quantification of eosinophilic inflammation by standard area measurements of MBP in ileitis and uninflamed ileum from 10 to 40 weeks of age. C: Correlation of eosinophilic inflammation with global histological score over time. Eosinophilia (open dot) and global histological score (black dots) were determined in mice before disease onset ( 5 weeks of age) and after disease onset (10 to 40 weeks of age). Pearson's correlation coefficient analysis showed significant correlation in the rate of increase in eosinophilia and histological measures of inflammation. D: mRNA expression levels for three members of the eotaxin family in whole ileal mRNA analysis. Data are expressed as mean fold change \pm SEM for inflamed versus age-matched uninflamed controls. ${ }^{*} * * * 0.001$, Student's $t$-test. $n=5$ per group.

(Figure 2A). Surface expression of double-positive cells $\left(\right.$ SiglecF $\left.{ }^{+} \mathrm{IL}-5 \mathrm{R} \alpha^{+}\right)$identified eosinophils within the granulocyte gate. A significant increase in SiglecF ${ }^{+} \mathrm{IL}-5 \mathrm{R} \alpha^{+}$ eosinophils was measured in both 14-week-old $(\sim 20$ fold; $P=0.06$ ) and 30-week-old SAMP1 ( $\sim$-fold; $P=$ 0.004 ), relative to controls (Figure $2 \mathrm{~B}$ ). Gating on the SiglecF ${ }^{+} \mathrm{IL}_{5 \mathrm{Ra}^{+}}$eosinophils or SiglecF $^{+} \mathrm{IL} 5 \mathrm{R} \alpha^{-}$undefined granulocyte populations from 30-week-old mice demonstrated that the mean fluorescence intensity MFI for CCR3 on SiglecF-positive granulocytes negative for IL-5R $\alpha$ was four times less than that of eosinophils positive for both SiglecF and IL-5R $\alpha(P<0.001)$ (Figure 2C). Thus, a population of SiglecF ${ }^{+} I L-5 R \alpha^{+}$CCR $3^{\text {high }}$ eosinophils is present in the lamina propria of 30 -week-old SAMP1 mice.

\section{Histopathological Progression of lleal Remodeling and Intestinal Permeability in Chronic lleitis}

Longitudinal development of remodeling in a spontaneous, chronic model of ileitis has not been examined previously. By 10 weeks of age, our histological analysis documented significant ileal remodeling, compared with uninflamed control mice (Figure 3A). These histological observations persisted through the 40 weeks cohort. The average villus:crypt ratio in control animals was $3 \pm 0.1$. However, at 10 weeks of age ratios in inflamed mice were reduced/blunted to $1.5 \pm$ $0.08(P<0.001)$ and decreased to $0.6 \pm 0.05(P<$ 0.001 ) by 40 weeks of age (Figure 3B). Hypertrophy of the muscularis propria was significantly greater at 10 weeks of age in ileitis, compared with control mice $[\sim 150 \mu \mathrm{m}$ versus $\sim 50 \mu \mathrm{m}(P<0.001)]$, a finding that persisted to 40 weeks of age (Figure 3D). This hypertrophy, due to reactive changes including cell swelling and intercellular edema, was similar in both circular and longitudinal muscle layers. Substantial increases in goblet cell numbers were identified by PAS staining (Figure 3C). Enumeration of percentage of goblet cells per villus revealed a greater than twofold increase in 10 -week-old mice with ileitis $(P<0.001)$, progressing to a greater than threefold increase by 40 weeks of age $(P<0.001)$, relative to uninflamed controls (Figure 3E). Eosinophilia significantly correlated with increased goblet cell component in villus epithelium $(r=0.93$; $P=0.01)$. Alterations in villus:crypt ratio, muscularis propria width, and goblet cell hyperplasia were established as early as 10 weeks of age. Villus blunting and goblet cell hyperplasia were progressive and sustained up to 40 weeks of age.

To assess the physiological effects of these histological changes over time, intestinal permeability was measured. Permeability was significantly increased in 
A

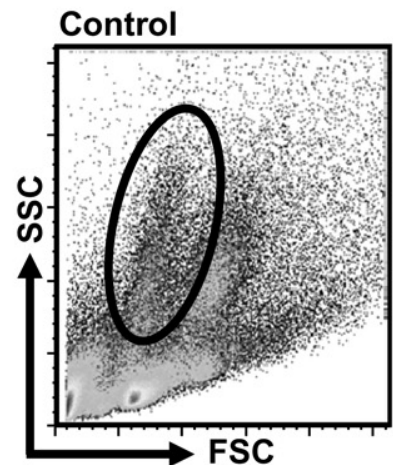

B

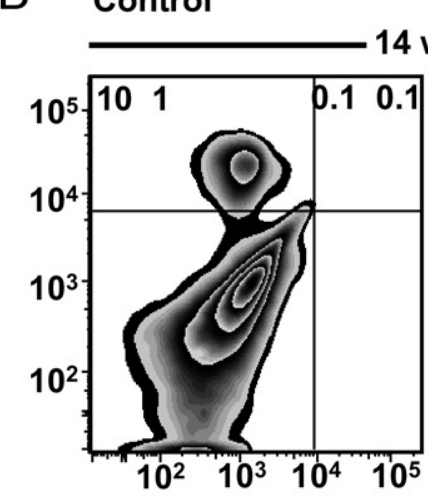

Ileitis

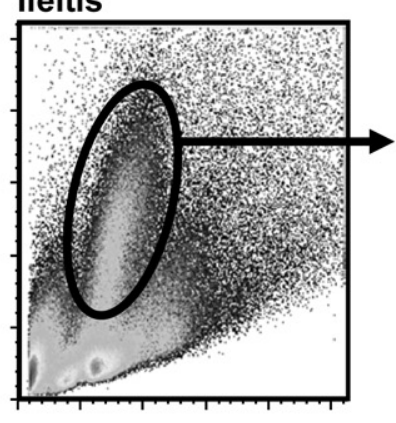

Ileitis

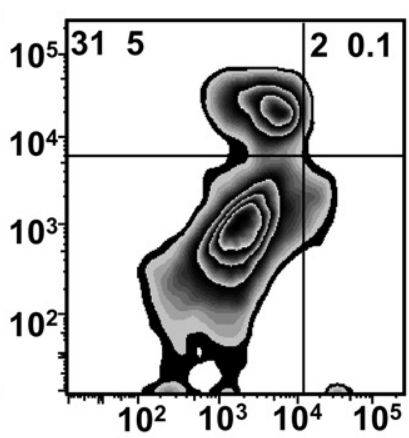

30 weeks
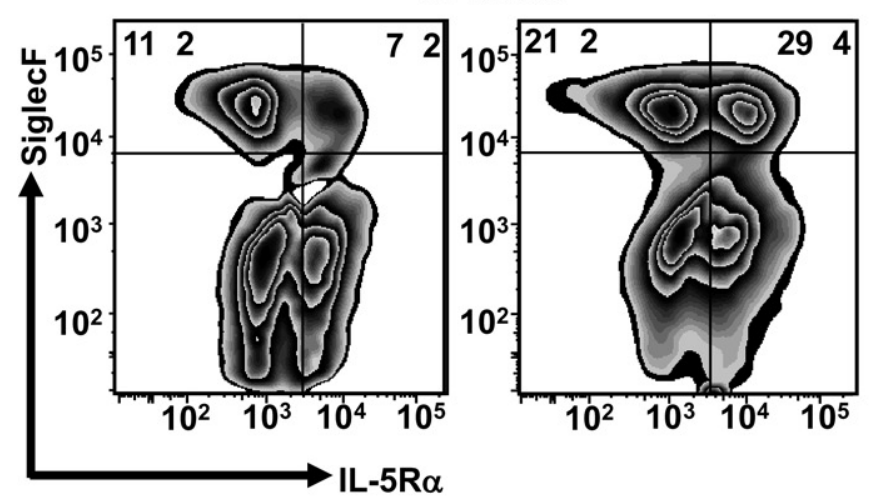

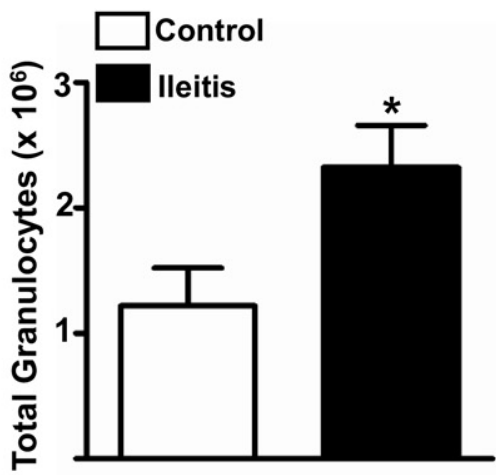

C
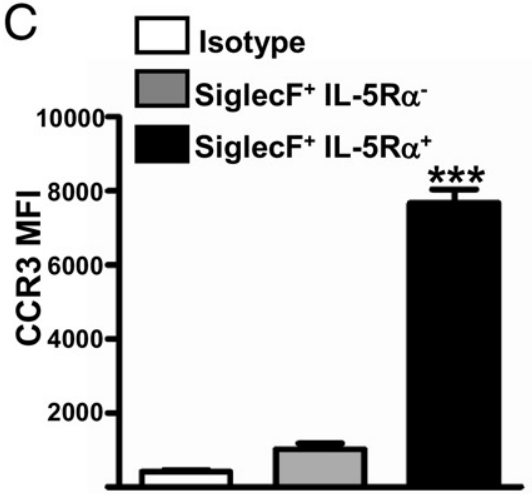

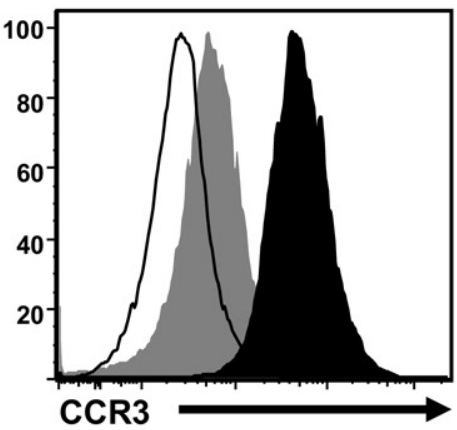

Figure 2. Flow cytometric examination of ileal eosinophilia. A: Representative density scatter plots and quantification of flow cytometric analysis of ileal lamina propria cells from 14-week-old inflamed and control mice. FSC, forward scatter; SSC, side scatter. B: Representative contour plots of 14- and 30-week-old lamina propria cells show expansion of SiglecF ${ }^{+}$and IL-5R $\alpha^{+}$ileal eosinophils in inflamed mice. C: Expression levels of CCR3 on double-positive $\left(\right.$ SiglecF ${ }^{+}$IL-5R $\alpha^{+}$) eosinophils as determined by mean fluorescence intensity MFI. Data are expressed as means \pm SEM. ${ }^{*} P<0.05$; **** $P<$ 0.001 .

mice with eosinophilic ileitis, compared with agematched uninflamed controls, beginning at 20 weeks of age (twofold increase; $P<0.05$ ) through to 40 weeks of age ( $\sim$ six-fold increase; $P<0.001)$ (Figure $3 F)$. To elucidate whether the functional impairment is associated with appearance of eosinophils, Pearson's correlation analysis between eosinophil numbers and permeability was performed. Intestinal eosinophilia, although not coincident with development of permeability, covaried with increased permeability over the time course analyzed ( $r=0.83 ; P=0.08)$.
Taken together, these results show an association between eosinophils and the development of chronic ileitis and remodeling.

Remodeling-Associated Gene Expression Profile Is Altered in Chronic lleitis

Consistent with histological and functional analysis, molecular markers of remodeling were notably increased. Quantitative real-time RT-PCR analysis revealed changes in genes related 
A

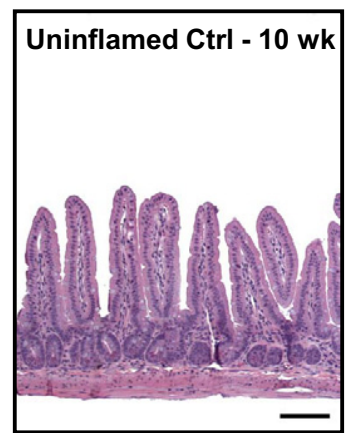

C

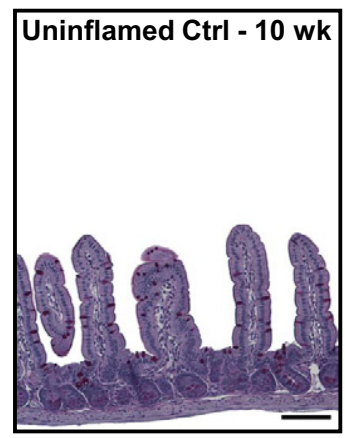

E

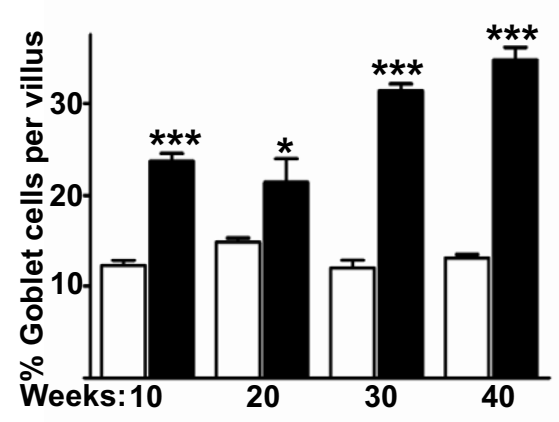

$\mathrm{F}$

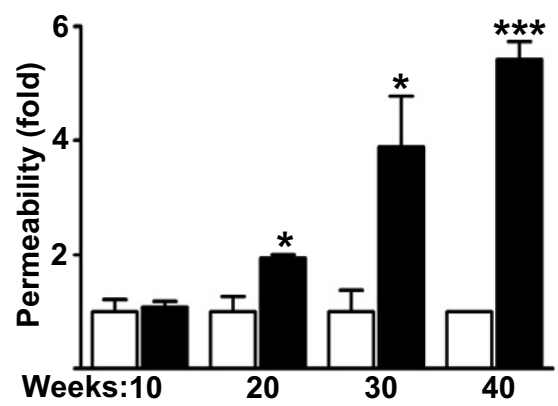

B $\square$ Uninflamed Control

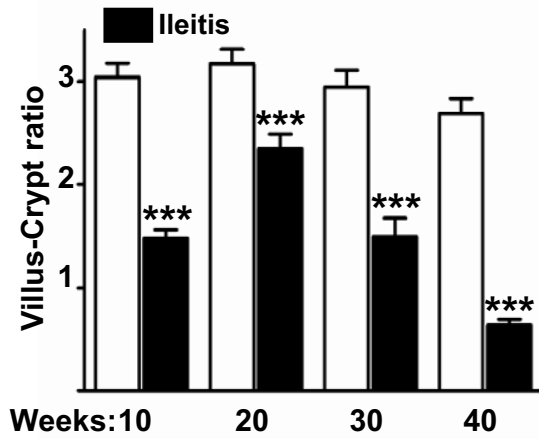

D

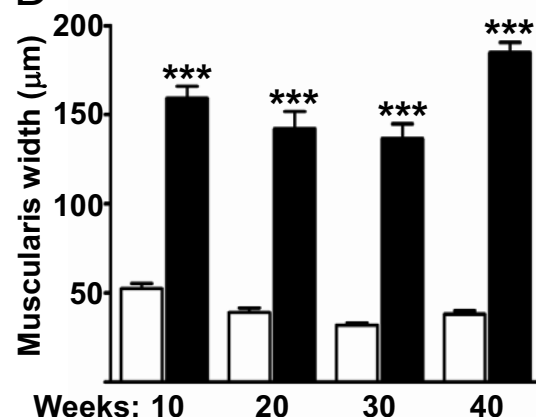

Weeks: 10

Figure 3. Histological features of chronic ileal remodeling. A: Representative H\&E-stained ileal tissues from control and inflamed mice at 10 weeks of age and inflamed mice at 40 weeks. B: Quantification of villus:crypt ratios in the ileum from 10- to 40-weekold mice. C: Representative PAS-stained ileal tissues from control and inflamed mice at 10 weeks of age and inflamed mice at 40 weeks. D: Muscularis hypertrophy in the ileum from 10 to 40 -week-old mice. E Quantification of the numbers of goblet cells as a percentage of the total number of villus epithelial cells from 10- to 40-week-old ilea. F: Intestinal permeability measured by FITC-labeled dextran ( $4 \mathrm{kDa})$ method, presented as fold increase versus agematched control mice from 10 to 40 weeks of age Scale bars $=100 \mu \mathrm{m}$. Data are expressed as means \pm SEM. ${ }^{*} P<0.05$; **ak $P<0.001 . n=5$ per group. to extracellular-matrix (ECM) synthesis and remodeling over time in ileitis and when compared with control uninflamed ileum (Table 1). Fibronectin mRNA levels were the most significantly increased ( $\sim 24.5 \pm 3.5$ fold change). Similar to ECM molecules, the mesenchymal cytoskeletal marker $\alpha$-smooth muscle actin ( $\alpha$-SMA) was also significantly elevated (3.0 \pm 0.4 fold change). Goblet cell-associated mucins were increased over time, as were a number of remodeling-associated metalloproteinases and TGF- $\beta$ family ligands.

Corresponding analysis of total collagen protein by Sircol assay revealed a significant increase, relative to uninflamed control mice, at 40 weeks of age (15 \pm 0.06 versus $11 \pm 2 \mathrm{ng} / \mu \mathrm{g}$ ileal tissue; $P<0.05)$. Molecular changes commenced by 10 weeks of age and developed through to 40 weeks of age.

\section{Eosinophilia and Remodeling Decrease after Dexamethasone Therapy}

To begin to assess eosinophil effect on remodeling, a broad-spectrum anti-inflammatory agent, dexamethasone, was administered to mice at 20 weeks of age. After treatment, histochemical and flow cytometric analysis showed that ileal eosinophilia (Figure 4A), peripheral (ie, spleen) inflammation (Figure $4 \mathrm{~B}$ ), and local MLN cellularity were significantly reduced (Figure $4 \mathrm{C}$ ). Along with diminished inflammation, markers of tissue remodeling (including muscularis hypertrophy and goblet cell hyperplasia) were significantly attenuated, compared with saline-treated inflamed controls (Figure 4, D and E). Thus, the broad-spectrum anti-inflammatory dexamethasone successfully reduced systemic inflammation, ileal eosinophilia, and remodeling in this model of chronic eosinophilic ileitis.

\section{Chronic Anti-CCR3 Antibody Administration Attenuates lleitis}

To diminish the effect of eosinophils on ileal remodeling, we used an antibody targeted at the chemotaxis receptor CCR3. ${ }^{27}$ The present study therefore targeted the eosinophil chemokine receptor CCR3. To directly assess the effect of eosinophils on inflammation and remodeling, antibody-medi- 
Table 1. Progressive Ileal Gene Expression Changes in Eosinophilic Ileitis

\begin{tabular}{|c|c|c|c|c|}
\hline Gene & 10 weeks & 20 weeks & 30 weeks & 40 weeks \\
\hline $\begin{array}{l}\text { COL1A1 } \\
\text { COL1A2 } \\
\text { COL3A1 } \\
\text { COL4A1 } \\
\text { FN1 } \\
\text { ACTA2 } \\
\text { VIM } \\
\text { CDH2 } \\
\text { MUC2 } \\
\text { MUC3A } \\
\text { MUC4 } \\
\text { MMP2 } \\
\text { MMP3 } \\
\text { MMP7 } \\
\text { MMP9 } \\
\text { MMP13 } \\
\text { TGFB1 } \\
\text { TGFB2 } \\
\text { TGFB3 }\end{array}$ & $\begin{array}{l}1.3 \pm 0.2 \\
1.3 \pm 0.3 \\
1.3 \pm 0.2 \\
1.4 \pm 0.3 \\
4.9 \pm 1.3 \\
1.2 \pm 0.1 \\
1.3 \pm 0.2 \\
0.8 \pm 0.1 \\
0.8 \pm 0.1 \\
1.3 \pm 0.7 \\
2.5 \pm 0.3^{\star \star *} \\
1.1 \pm 0.2 \\
0.8 \pm 0.1 \\
1.4 \pm 0.3 \\
1.3 \pm 0.4 \\
0.4 \pm 0.1 \\
1.4 \pm 0.2 \\
0.9 \pm 0.2 \\
1.2 \pm 0.2\end{array}$ & 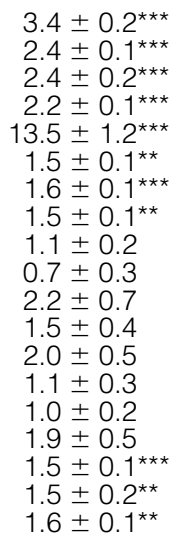 & 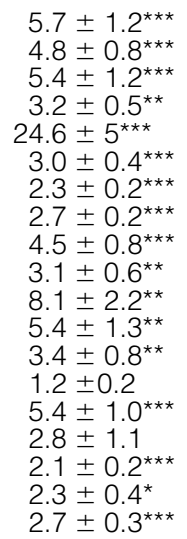 & $\begin{array}{c}6.2 \pm 0.06^{\star \star} \\
4.2 \pm 0.7^{\star \star} \\
4.1 \pm 0.7^{\star \star} \\
3.9 \pm 0.7^{\star} \\
24.5 \pm 3.5^{\star \star \star} \\
2.2 \pm 0.2^{\star \star} \\
1.9 \pm 0.2^{\star} \\
2.6 \pm 0.3^{\star \star} \\
2.8 \pm 0.4 \\
1.6 \pm 0.3 \\
2.7 \pm 0.5 \\
2.8 \pm 0.3^{\star \star} \\
1.6 \pm 0.3 \\
0.7 \pm 0.1 \\
4.3 \pm 0.9^{\star} \\
3.1 \pm 0.5 \\
1.6 \pm 0.1 \\
2.8 \pm 0.3^{\star \star} \\
1.8 \pm 0.3\end{array}$ \\
\hline
\end{tabular}

Data are expressed as mean fold change \pm SEM versus age-matched, uninflamed controls. $n=5$ per group

${ }^{*} P<0.05,{ }^{*} P<0.01$, and ${ }^{* * *} P<0.001$, Student's -test.

†Previously MUC3.

ated inhibition of eosinophilia was performed at two time points, upon disease development (4 to 14 weeks of age) and at chronic disease (20 to 30 weeks of age). ${ }^{25}$ When antibody was administered from 4 to 10 weeks of age, during the time when inflammation was developing, eosinophilia was reduced, relative to lgG-treated ileitis controls $(78 \pm 8.9$ versus $51 \pm 4.6$ eosinophils per high-power field; $P=0.01$ ). This pretreatment of ileitis targeted at eosinophilia also significantly reduced overall histological indices of inflammation and chronic architectural disruption $(>30 \% ; P=0.05)$. When weekly anti-CCR3 antibody infusions were administered from 20 to 30 weeks of age, during a time of maximal inflammation, eosinophilic ileal inflammation was also significantly decreased, relative to IgG-treated ileitis controls (Figure 5, A and B). This reduction in eosinophilia was found in all compartments of ileal tissue, lamina propria through to muscle, with a particular reduction in eosinophil accumulation at the basal lamina region and approximately a 50\% reduction in overall tissue eosinophils per high-power field. Eotaxin 1 (CCL11) and eotaxin 2 (CCL24) were significantly reduced after anti-eosinophil targeted antibody treatment compared with IgG-treated ileitis (Figure 5C; see also Supplemental Figure S1 at $h t t p: / /$ ajp.amjpathol.org). This may be explained by the overall reduction in inflammatory infiltrate (Figure 6A), likely including reduced numbers of macrophages, which are the predominant source of eotaxin in DSS colitis. ${ }^{7}$ In addition, as an indirect molecular measure of reduced eosinophil presence in the tissue, mRNA expression of the eosinophil surface marker and eotaxin receptor CCR3 was significantly reduced after treatment.

\section{Anti-CCR3 Antibody Treatment Results in Decreased Severity of lleal and Local Lymphoid Inflammation}

Absence of eosinophils in a lung model of eosinophilassociated pathology (the OVA asthma model) resulted
A

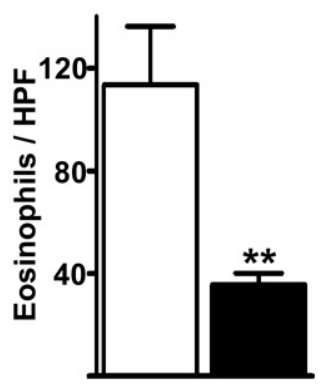

B

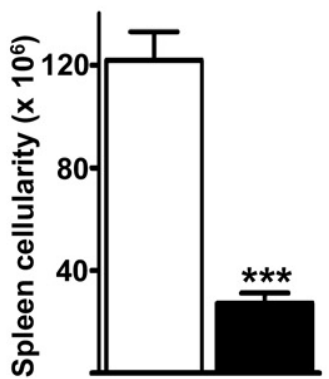

C

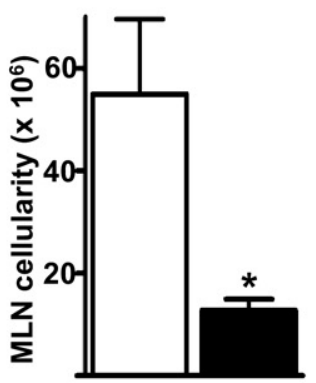

$\mathrm{D}$

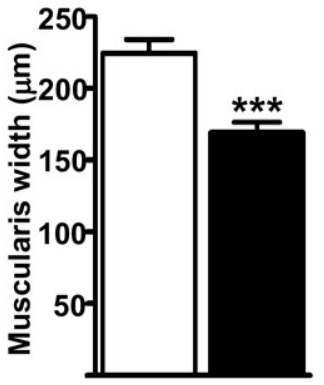

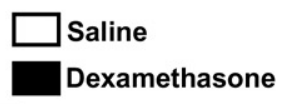

E

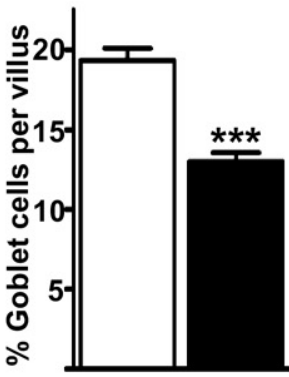

Figure 4. Assessment of ileitis and remodeling after dexamethasone treatment. A: Quantification of eosinophils by MBP immunostaining from saline control and dexamethasone-treated SAMP1 mice. B and C: Absolute numbers for spleen and MLN cellularity from control and treated mice. D and E: Quantification of muscularis width and percent goblet cells per villus from saline control and dexamethasone-treated ilea stained with H\&E or PAS. Data are expressed as means \pm SEM. ${ }^{*} P<0.05 ;{ }^{* * *} P<0.01 ;{ }^{* * * *} P<0.001 . n=4$ per group. 
A

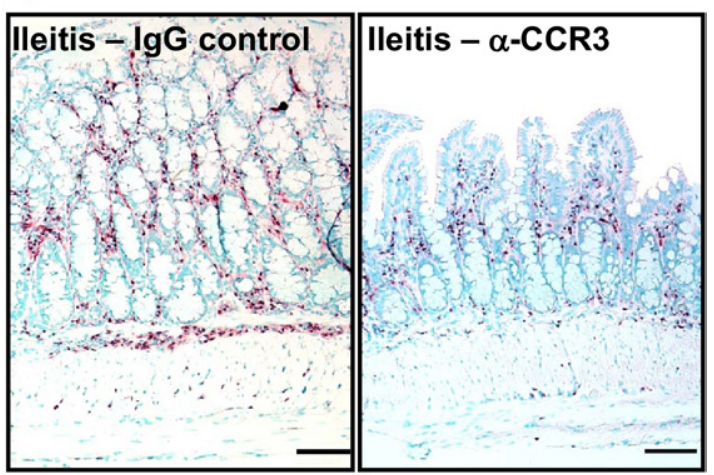

B

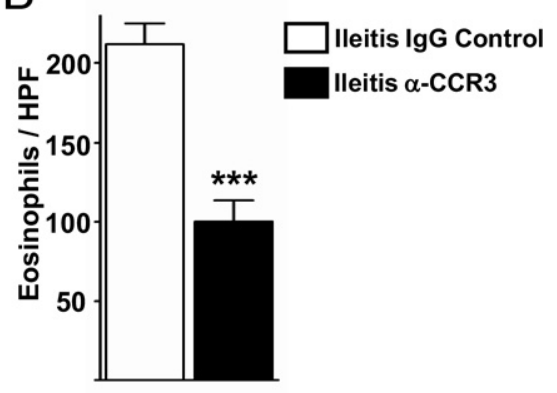

C
\begin{tabular}{|lll|}
\hline Ileitis & & \\
\hline GENE & $\alpha$-CCR3 & $P$ value \\
\hline CCL11 & $0.3 \pm 0.1$ & $P<0.01$ \\
CCL24 & $0.3 \pm 0.1$ & $P<0.01$ \\
CCR3 & $0.3 \pm 0.1$ & $P<0.01$ \\
\hline
\end{tabular}

Figure 5. Anti-CCR3 treatment attenuates ileal eosinophilia. Mice with established ileitis were injected with isotype control $(n=7)$ or anti-CCR3 antibody $(n=6)$ weekly from 20 to 30 weeks of age. A: Representative MBP-immunostained ileum localizes eosinophils with and without treatment at 30 weeks of age. Scale bars $=100 \mu \mathrm{m}$. B: Eosinophilic infiltration into ileal tissues was quantified using standard area measurements of MBP immunostaining. Data are presented as numbers of eosinophils per high-power field (HPF). Data are expressed as means \pm SEM. ${ }^{* * * *} P<0.001 . n=6$ or 7 per group. C: Expression of three eotaxin family members was assessed in whole ileal tissue total mRNA isolates after control or anti-CCR3 treatment, using TaqMan qRT-PCR. Data are presented as mean fold change \pm SEM from control treatments. $n=6$ or 7 per group.

in deficient recruitment of effector T cells and attenuated pathology. ${ }^{28}$ We therefore sought to investigate the effect of anti-CCR3 treatment on lymphocyte recruitment in this chronic model of ileitis. After 10 weeks of anti-CCR3 antibody treatment (from 20 to 30 weeks of age), histopathological indices of tissue inflammation were significantly reduced, compared with IgG-treated mice (Figure $6 A)$. Although splenic cellularity remained unchanged after treatment, MLN cellularity was significantly decreased (Figure 6B). Characterization of the local MLN cellularity identified a uniform and significant decrease in $\mathrm{CD}^{+}(20 \% ; P<0.001), \mathrm{CD}^{+}(24 \% ; P=0.05)$, and $\mathrm{CD}^{+}{ }^{+}(26 \% ; P=0.001)$ lymphocytes (Figure 6C). Further examination of T-lymphocyte populations revealed significant reduction in $\mathrm{CD}^{+}$and $\mathrm{CD}^{+}$effector $\mathrm{T}$ cells in
anti-CCR3 treated tissues compared to IgG treated controls (CD44 ${ }^{\text {high }} \mathrm{CD}_{2} \mathrm{~L}^{\text {neg: }} \mathrm{CD}^{+} 37 \%, P<0.05$, and $\left.\mathrm{CD}^{+} 50 \%, P<0.05\right)$, in addition to $\mathrm{CD}^{+}$and $\mathrm{CD}^{+}$ central memory T cells (CD44 ${ }^{\text {high }}$ CD62L high: $\mathrm{CD}^{+} 44 \%$, $P<0.01$, and $\left.\mathrm{CD}^{+} 39 \%, P<0.001\right)$ after anti-eosinophil treatment (Figure 6, D and E). In addition, molecular characterization of immune function revealed a significant reduction in $\mathrm{IL}-5$ and $\mathrm{IL}-13$ cytokine expression ( $>50 \%$ reduction; $P<0.05$ ) (Figure $6 \mathrm{~F}$; see also Supplemental Figure S1 at $h$ ttp://ajp.amjpathol.org). Finally, previous studies had determined a reduction in levels of T- and B-lymphocyte chemokines in pulmonary inflammation in mice congenitally deficient in eosinophils. We sought to determine whether such a mechanism can explain the reduction in lymphocyte recruitment in the anti-CCR3-mediated reduction in eosinophils in this mouse model of Crohn's-like ileitis. A significant reduction in lymphocyte chemokines CCL17 (50\%; $P<0.05)$ and CCL22 (50\%; $P<0.05)$ was observed, in addition to reduction of CCR4 (50\%; $P<0.05)$, their cognate receptor, on $\mathrm{T}$ - and B-lymphocytes in mice after anti-CCR3 treatment (Figure 6F; see also Supplemental Figure S1 at http://ajp.amjpathol.org).

\section{Attenuated Eosinophilia Is Sufficient to Reverse Histological and Molecular Measures of lleal Remodeling}

Similar to previous findings regarding the lung, ${ }^{19,25,29}$ targeted reduction of eosinophilia was associated with a significant improvement in histological remodeling. Diminished goblet cell hyperplasia was observed, with post-treatment levels reaching levels similar to those of age-matched control uninflamed mice (Figure 7, A and B). Muscularis width decreased, and villus:crypt ratios reverted and approached normal ratios of age-matched uninflamed control mice (Figure 7, C-E).

Similar to our findings from histological and cellular investigations, analysis of previously measured mRNA expression associated with remodeling revealed a considerable reduction compared with IgG control-treated ileitis. The most up-regulated gene, fibronectin, was significantly reduced, as were a number of collagens, the cytoskeletal molecules vimentin and $\alpha$-SMA, MMPs, and the mesenchymal cell adhesion molecule $\mathrm{N}$-cadherin (Figure 7F; see also Supplemental Figure S1 at http:// ajp.amjpathol.org). Consistent with the histological measure of reduction in goblet cell hyperplasia, MUC2 and MUC4 expression was significantly reduced after eosinophil reduction (Figure 7F; see also Supplemental Figure S1 at http://ajp.amjpathol.org). Functional assessment of the mucosa revealed improvement in intestinal permeability after treatment-induced restoration of tissue architecture. Permeability was reduced by $21 \%$, compared with IgG control-treated ileitis, after 10 weeks of antiCCR3 treatment (from 20 to 30 weeks of age). This finding suggests a role for, but not a dependence on, eosinophilia in the development of intestinal permeability in this mouse model of ileitis. 
A
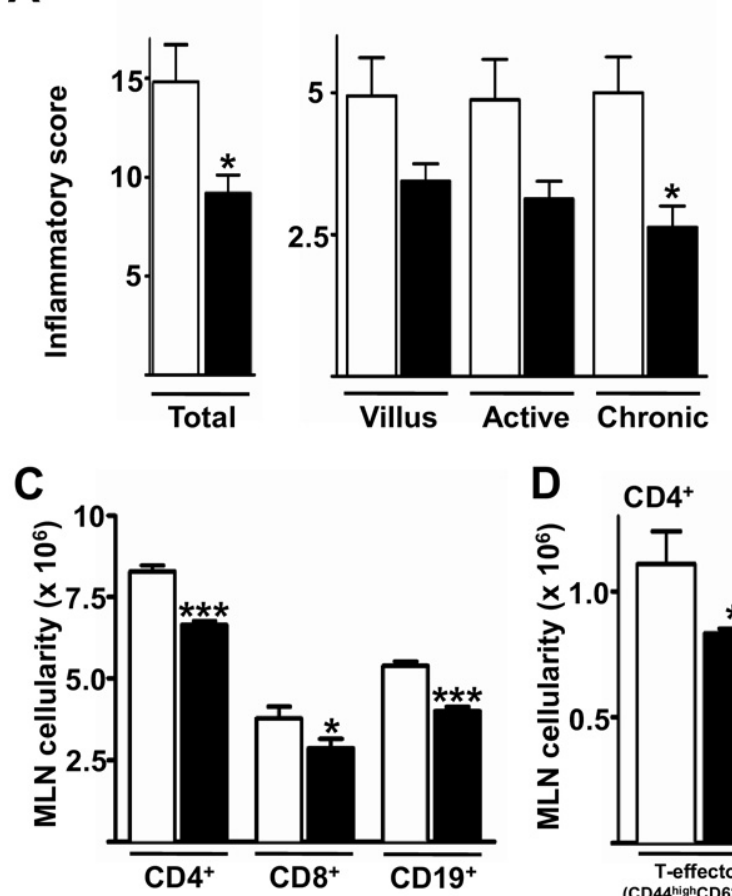

$\mathbf{F}$

\begin{tabular}{|lll|}
\hline Ileitis & & \\
\hline GENE & $\alpha$-CCR3 & $P$ value \\
\hline IL5 & $0.4 \pm 0.1$ & $P<0.05$ \\
IL13 & $0.3 \pm 0.1$ & $P<0.05$ \\
TNF & $0.7 \pm 0.1$ & $P=0.16$ \\
IFNG & $0.6 \pm 0.1$ & $P=0.42$ \\
\hline CCL17 & $0.5 \pm 0.1$ & $P<0.05$ \\
CCL22 & $0.5 \pm 0.1$ & $P<0.05$ \\
CCR4 & $0.5 \pm 0.1$ & $P<0.05$ \\
\hline
\end{tabular}

B
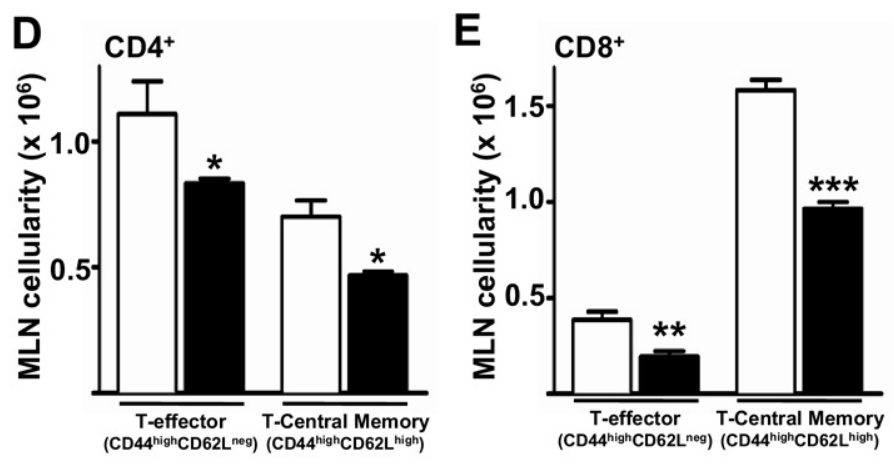

Figure 6. Assessment of cellular, histological, and molecular parameters of inflammation after anti-CCR3 antibody administration. A: Histological quantification of ileal inflammatory indices (global, villus distortion, active, and chronic). B: Absolute cell counts of the MLN and spleen. C: Absolute numbers of MLN-associated $\mathrm{CD}_{4}^{+}, \mathrm{CD}^{+}$, and $\mathrm{CD} 19^{+}$cells within a lymphocyte gate. D: Absolute numbers of $\mathrm{CD}^{+}$T-effector $\left(\mathrm{T}_{\mathrm{EM}}\right.$ : $\left.\mathrm{CD} 44^{\text {high }} \mathrm{CD} 62 \mathrm{~L}^{\text {neg }}\right)$ and $\mathrm{T}$-central memory $\left(\mathrm{T}_{\mathrm{CM}}: \mathrm{CD} 44^{\text {high }} \mathrm{CD} 62 \mathrm{~L}^{\text {high }}\right)$ cells. E: $C D 8^{+} T_{E M}$ ) and $T_{C M}$ cells quantified by flow cytometry. F: Molecular analysis of Th1- and Th2-associated cytokines and lymphocyte-associated chemokines from whole ileal tissue RNA from 30-week-old control or anti-CCR3-treated ileitis, presented as mean fold change versus 30-weekold control. Data are expressed as means \pm SEM. ${ }^{*} P<0.05 ;{ }^{* *} P<0.01$; ***: $P<0.001$. $n=6$ or 7 per group.
Taken together, the present results demonstrate that antibody-mediated reduction of eosinophilic burden leads to significant reduction in overall inflammation and remodeling in murine Crohn's-like ileitis.

\section{Discussion}

Mucosal eosinophilia characterizes a number of chronic diseases, including inflammatory bowel disease (IBD). On stimulation, these granulated leukocytes can release a number of proinflammatory and remodeling-associated factors. Numerous mediators produced by eosinophils have been associated with acute intestinal damage, and recent evidence explicitly implicates these cells or their products in chronic remodeling or fibrotic processes in other locations in the intestinal tract. For instance, patients with eosinophilic esophagitis can develop strictures, and in murine models of esophagitis develop IL-5dependent remodeling and fibrosis. ${ }^{20,30,31}$ In the present study, we hypothesized that chronic eosinophilic inflammation directly contributes to ileal remodeling in IBD. We found that eosinophilic ileitis was associated with progressive histological, functional, and molecular markers of remodeling. Pharmacological reduction of eosinophils either by the broad-spectrum anti-inflammatory agent dexamethasone or by specific antibody-mediated targeting via the CCR3 receptor decreased all of these indices. Taken together, these findings support a role for eosinophils in chronic ileal remodeling.

Tissue remodeling is a vital process in the life cycle of mucosal tissues. Tissue remodeling refers to the renovative and/or adaptive process that develops to preserve organ function during tissue homeostasis and in repair after injury. Cellular and molecular features characterizing remodeling include goblet cell hyperplasia, muscular hyperplasia and hypertrophy, neoangiogenesis, and extracellular matrix production, as well as changes in the balance of matrix metalloproteinases and tissue metallo- 
IBD, Eosinophils, and Remodeling 2311 AJP November 2011, Vol. 179, No. 5

A

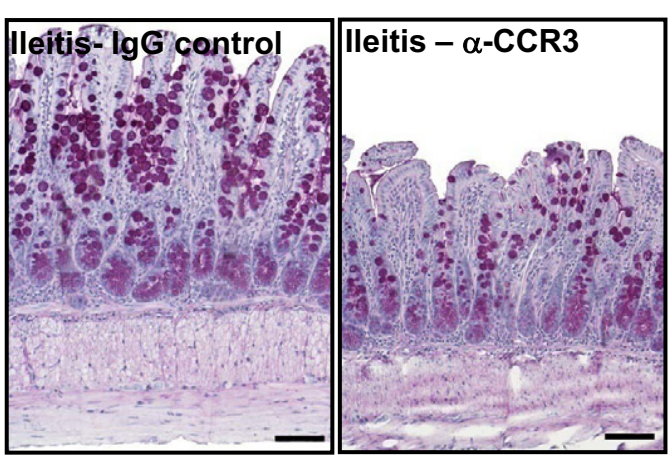

C

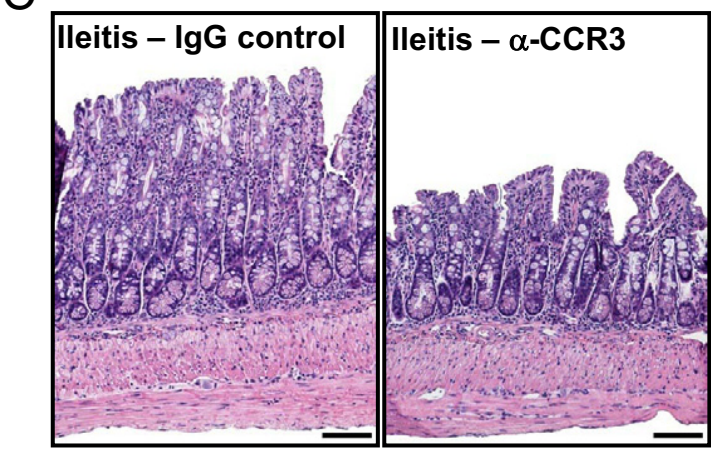

D

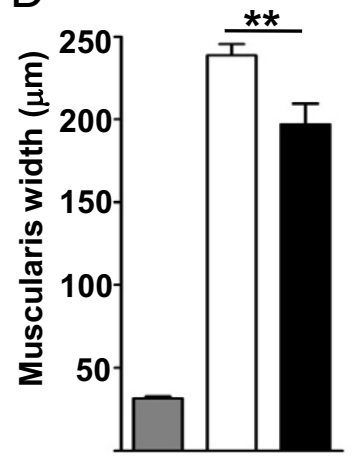

B

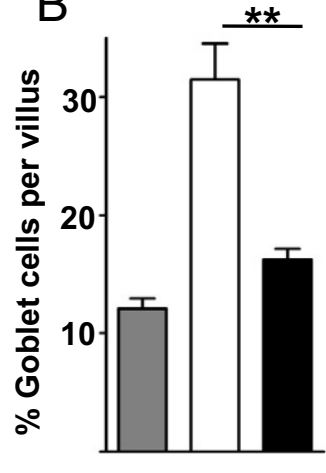

$\mathrm{F}$

\begin{tabular}{|lll|}
\hline Ileitis & & \\
\hline GENE & $\alpha$-CCR3 & $P$ value \\
\hline COL1A1 & $0.4 \pm 0.1$ & $P<0.001$ \\
COL1A2 & $0.5 \pm 0.1$ & $P<0.01$ \\
COL3A1 & $0.4 \pm 0.1$ & $P<0.01$ \\
COL4A1 & $0.5 \pm 0.1$ & $P<0.01$ \\
\hline FN1 & $0.4 \pm 0.1$ & $P<0.01$ \\
ACTA2 & $0.8 \pm 0.2$ & $P<0.01$ \\
VIM & $0.6 \pm 0.1$ & $P<0.05$ \\
CDH2 & $0.7 \pm 0.1$ & $P=0.005$ \\
\hline MUC2 & $0.5 \pm 0.1$ & $P<0.001$ \\
MUC3A & $0.9 \pm 0.1$ & $P=0.26$ \\
MUC4 & $0.4 \pm 0.1$ & $P<0.001$ \\
\hline MMP2 & $0.4 \pm 0.1$ & $P<0.001$ \\
MMP3 & $0.7 \pm 0.1$ & $P=0.06$ \\
MMP9 & $0.4 \pm 0.1$ & $P<0.05$ \\
MMP13 & $0.4 \pm 0.1$ & $P<0.01$ \\
\hline TGFB1 & $0.5 \pm 0.1$ & $P<0.05$ \\
TGFB2 & $0.5 \pm 0.1$ & $P=0.15$ \\
TGFB3 & $0.7 \pm 0.1$ & $P=0.16$ \\
\hline
\end{tabular}

Figure 7. Assessment of ileal tissue remodeling in eosinophil targeted therapy of chronic eosinophilic ileitis. A: Representative PAS-stained ileal tissue sections. B: Quantification of the numbers of goblet cells as a percentage of the total number of villus epithelial cells from 30 -week-old uninflamed control and inflamed isotype control or anti-CCR3-treated ilea. C: Representative H\&E-stained ileal tissue sections. D: Quantification of muscular thickening. E: Villus:crypt ratios in the ileum from 30-week-old uninflamed control, inflamed isotype control, and anti-CCR3-treated ilea. Scale bars $=100 \mu \mathrm{m}$. Data are expressed as means \pm SEM. ${ }^{* *} P<0.01 . n=6$ or 7 per group. F: Table of fold change in mRNA expression after anti-CCR3 treatment of ileitis.

proteinase inhibitors. The same processes associated with homeostatic tissue regeneration may lead to pathological processes. Lack of control of tissue repair during chronic inflammation may lead to intestinal stricture formation. Thus, the fine balance between extracellular matrix deposition and degradation defines the boundary between health and disease.

Although the pathogenesis of IBD-related strictures is unknown, a series of studies have provided some insight into potential mechanisms for this life-altering and costly complication. Central to this is the activation of mesenchymal cells by inflammatory responses to tissue injury. Although fibroblasts are important mediators of fibrosis, other cells also are critical to the remodeling process; smooth muscle cells, recruited bone marrow stem cells that differentiate into fibroblast-like cells, and epithelial and endothelial cells in transdifferentiation to a mesenchymal state may all contribute to intestinal dysfunction. ${ }^{32}$ An important factor is exposure of intestinal mesenchymal cells, including fibroblasts, to profibrogenic 
mediators such as IL-13, TGF- $\beta$, TNF, and others that induce or suppress signaling of remodeling molecules (including collagens, tissue inhibitors of metalloproteinases, and MMPs). The production of chemokines may also be key in a situation in which inflammation-associated fibrosis occurs. With the present study, we demonstrate that disease progression is associated with increased eosinophil-attracting chemokines CCL11 and CCL24. This eosinophilic ileitis is also associated with an increase in goblet cells and hypertrophy of the muscularis propria. Increases in collagen, other ECM molecules, MMPs, IL-13, and TGF- $\beta$ are also involved in pathogenesis in this model. Inhibition of eosinophilia by dexamethasone or by antibody-mediated methods leads to a significant regression of these pathological responses in this chronic ileitis. Thus, our data support a role for eosinophils in gastrointestinal remodeling in chronic ileitis.

Various studies targeting the reduction of eosinophilia have identified potential roles for eosinophils in remodeling and fibrotic process in other organ systems. ${ }^{25,33-36}$ Inhibition of eosinophilic inflammation with anti-CCR3 antibody resulted in a decrease in mucus accumulation and diminution of airway hyperresponsiveness after airway challenge in a sensitized mouse. ${ }^{25}$ In a pulmonary model of airway injury, antibody inhibition of IL-5 led to improvement in lung function and airway remodeling, ${ }^{37,38}$ whereas both PHIL and $\Delta$ dbIGATA mouse models genetically deficient in eosinophils define a critical role for eosinophils in allergic airway remodeling, one that involves mucus, collagen, and smooth muscle accumulation. ${ }^{35,36}$ Similarly, eosinophils are rich sources of TGF- $\beta$, and asthma patients with subepithelial fibrosis demonstrate increased expression of eosinophil-derived TGF- $\beta$ mRNA and protein. ${ }^{39}$ Patients with hypereosinophilic syndrome can develop endomyocardial fibrosis, a devastating complication, and a finding thought to be related to eosinophil cationic protein. ${ }^{40}$ Treatment of asthma patients with anti-IL-5 mepolizumab revealed a significant reduction of eosinophilia correlated with substantial reduction of subepithelial basement membrane thickness and ECM expression in biopsies obtained from patients after treatment. ${ }^{19}$ Consistent with these findings, the present results revealed a reduction in goblet cells, reduced expression of numerous molecules associated with remodeling, and diminished ECM production after anti-eosinophil treatment.

Although eosinophils are closely linked with airway remodeling, emerging evidence supports a role for eosinophil participation in intestinal remodeling. For instance, recent work examining the pathogenesis of eosinophilic esophagitis showed the presence of pSMAD-positive TGF- $\beta$-positive eosinophils in remodeled tissues. ${ }^{31}$ Murine models of eosinophilic esophagitis have demonstrated the IL-5 dependency of collagen deposition in inflamed tissues. ${ }^{30}$ Finally, chronic eosinophilia is associated with isolated and long-segment strictures in eosinophilic esophagitis. In support for the role of eosinophils in ileitis, we observed a reduction in IL-5 and TGF- $\beta$ after anti-eosinophil treatment. Reduced eosinophils in our model led to significant re- duction in ileal remodeling and a large set of associated molecules. Taken together, these results support the eosinophil as a potential therapeutic target in prevention of IBD-associated strictures.

The most dramatically increased molecule in remodeling was the ECM component fibronectin. This molecule is involved in the adhesion, retention, and potential activation of eosinophils in the interstitial space..$^{41}$ Eosinophils have been reported to induce the synthesis of fibronectin in intestinal myofibroblasts, ${ }^{42}$ defining a direct role for eosinophils in ECM production and in myofibroblast activation, in addition to maintaining an environment suitable for eosinophil retention and activation. As shown in previous studies examining lung injury, we found that reduced eosinophils and thus remodeling mediators, including fibronectin, led to a partial reversal of ileal inflammation and remodeling. ${ }^{19,25,28,29}$

Eosinophils are well-known sources of functional IL$13,{ }^{43}$ a molecule associated with remodeling and fibrosis. ${ }^{44}$ For instance, a number of studies have highlighted the role of IL-13 as a central mediator driving the major asthmatic pathologies, including eosinophilia, mucus accumulation, fibrosis, and airway hyperresponsiveness. ${ }^{44}$ Parasite-mediated increases in intestinal IL-13 are critical for intestinal goblet cell hyperplasia and mucus secretion leading to worm expulsion and host protection. ${ }^{45}$ Fichtner-Feigl et al ${ }^{46}$ determined that IL-13 induction is critical in a model of chronic TGF- $\beta 1$-dependent tissue fibrosis triggered by 2,4,6-trinitrobenzene-induced colitis. Our previous work demonstrated increased IL-13 in SAMP1 ileal tissues, ${ }^{10}$ and here we report a progression of goblet cell hyperplasia, muscle hypertrophy, and eosinophil accumulation over time in ileitis. Anti-eosinophil treatment led to a decrease in IL-13 expression, as well as to diminished ileal remodeling. Although this point is beyond the scope of the present study, eosinophil-derived IL-13 may play a central role in the underlying pathogenesis of eosinophil-associated remodeling.

Mice congenitally deficient in eosinophils (PHIL and $\Delta$ dbIGATA mice) show no alteration in normal circulating lymphocyte numbers, and there is no effect on normal leukocyte development. ${ }^{36,47}$ In the present study, eosinophil attenuation resulted in a local, but not systemic, decrease in lamina propria leukocytes, including T-effector memory and T-central memory lymphocytes. Of note, defective recruitment of T-effector memory cells that resulted in attenuated inflammation was described previously in the eosinophil-less PHIL mouse after OVA-challenge. ${ }^{28}$ In the PHIL model, the presence of eosinophils was necessary for the expression of chemokines required for recruitment of effector $T$ cells and the subsequent induction of pulmonary remodeling and tissue dysfunction. Recent studies of a model of allergic asthma in $\Delta$ dbIGATA mice determined a critical role for eosinophil derived IL-13 in the recruitment of T lymphocytes and the development of airway hyperresponsiveness. ${ }^{48}$ Our findings also demonstrate reduced lymphocyte chemokines and IL-13 after treatment targeting eosinophils, suggesting a similar critical role for eosinophils in the development of intestinal inflammation and remodeling. Early studies of SAMP1 models of ileitis suggest the central 
role of T cells in the induction of inflammation. ${ }^{15,49}$ More recent evidence, however, may suggest a nonhematopoietic origin of inflammation. ${ }^{22}$ Thus, reduction in both eosinophils and T cells is of importance for successful treatment of disease in these SAMP1 models and may point to a potential role for eosinophils in modulating the local immune response in the intestine, however further investigation is required.

Our previous work identified distinct differences between the ileal immune profile in the SAMP1 and the SAMP1/YitFc model. The SAMP1 ileal cytokine profile switched to a Th2 predominant profile with reduced to no expression of Th1 cytokines, however the SAMP1/YitFc remains predominantly Th1 with low levels of Th2 cytokines. ${ }^{10}$ Early studies with the SAMP1/Yit model of ileitis suggest the central role of $T$ cells in the induction of inflammation. ${ }^{15,49}$ Other evidence points to a nonhematopoietic origin of inflammation in the SAMP1/YitFc model. ${ }^{22}$ Increased numbers of eosinophils are present in both the SAMP1 and the SAMP1/YitFc ilea. Our data support a functional role for eosinophils in the ileal mucosa, associated in particular with remodeling events in this SAMP1 Crohn's-like mouse model of eosinophilic ileitis.

Here, we have reported that eosinophils play a significant role in murine ileal remodeling and fibrosis. Further studies are planned to address specific eosinophil-derived mediators contributing to this response. Because the pathogenesis of fibrosis and strictures in IBD is largely unknown, our findings add to a growing body of literature aimed at understanding this problem and may add the eosinophil and eosinophil-derived mediators as candidate targets for novel therapies for IBD-related strictures.

\section{Acknowledgment}

We thank Dr. Zhaoxing Pan for his statistical expertise and guidance with data analysis.

\section{References}

1. Silverstein MD, Loftus EV, Sandborn WJ, Tremaine WJ, Feagan BG, Nietert PJ, Harmsen WS, Zinsmeister AR: Clinical course and costs of care for Crohn's disease: Markov model analysis of a populationbased cohort. Gastroenterology 1999, 117:49-57

2. Cosnes J, Nion-Larmurier I, Beaugerie L, Afchain P, Tiret E, Gendre JP: Impact of the increasing use of immunosuppressants in Crohn's disease on the need for intestinal surgery [Erratum appeared in Gut 2005;54:734]. Gut 2005, 54:237-241

3. Abraham C, Cho JH: IL-23 and autoimmunity: new insights into the pathogenesis of inflammatory bowel disease. Annu Rev Med 2009, 60:97-110

4. Hogan SP: Functional role of eosinophils in gastrointestinal inflammation. Immunol Allergy Clin North Am 2009, 29:129-140, xi

5. Wedemeyer J, Vosskuhl K: Role of gastrointestinal eosinophils in inflammatory bowel disease and intestinal tumours. Best Pract Res Clin Gastroenterol 2008, 22:537-549

6. Woodruff SA, Masterson JC, Fillon S, Robinson ZD, Furuta GT: Role of eosinophils in inflammatory bowel and gastrointestinal diseases. J Pediatr Gastroenterol Nutr 2011, 52:650-661

7. Lampinen M, Rönnblom A, Amin K, Kristjansson G, Rorsman F, Sangfelt $P$, Säfsten $B$, Wagner $M$, Wanders $A$, Winqvist $O$, Carlson $M$ :
Eosinophil granulocytes are activated during the remission phase of ulcerative colitis. Gut 2005, 54:1714-1720

8. Ahrens R, Waddell A, Seidu L, Blanchard C, Carey R, Forbes E, Lampinen M, Wilson T, Cohen E, Stringer K, Ballard E, Munitz A, Xu H, Lee N, Lee JJ, Rothenberg ME, Denson L, Hogan SP: Intestinal macrophage/epithelial cell-derived CCL11/eotaxin-1 mediates eosinophil recruitment and function in pediatric ulcerative colitis. J Immunol 2008, 181:7390-7399

9. Wagner M, Peterson CG, Ridefelt P, Sangfelt P, Carlson M: Fecal markers of inflammation used as surrogate markers for treatment outcome in relapsing inflammatory bowel disease. World J Gastroenterol 2008, 14:5584-5589; discussion 5588

10. McNamee EN, Wermers JD, Masterson JC, Collins CB, Lebsack MD, Fillon S, Robinson ZD, Grenawalt J, Lee JJ, Jedlicka P, Furuta GT, Rivera-Nieves J: Novel model of TH2-polarized chronic ileitis: the SAMP1 mouse. Inflamm Bowel Dis 2010, 16:743-752

11. Vieira AT, Fagundes CT, Alessandri AL, Castor MG, Guabiraba R, Borges VO, Silveira KD, Vieira EL, Gonçalves JL, Silva TA, Deruaz M, Proudfoot AE, Sousa LP, Teixeira MM: Treatment with a novel chemokine-binding protein or eosinophil lineage-ablation protects mice from experimental colitis. Am J Pathol 2009, 175:2382-2391

12. Forbes E, Murase T, Yang M, Matthaei KI, Lee JJ, Lee NA, Foster PS, Hogan SP: Immunopathogenesis of experimental ulcerative colitis is mediated by eosinophil peroxidase. J Immunol 2004, 172:5664-5675

13. Shichijo K, Makiyama K, Wen CY, Matsuu M, Nakayama T, Nakashima M, Ihara M, Sekine I: Antibody to eosinophil cationic protein suppresses dextran sulfate sodium-induced colitis in rats. World $J$ Gastroenterol 2005, 11:4505-4510

14. Furuta GT, Nieuwenhuis EE, Karhausen J, Gleich G, Blumberg RS, Lee JJ, Ackerman SJ: Eosinophils alter colonic epithelial barrier function: role for major basic protein. Am J Physiol Gastrointest Liver Physiol 2005, 289:G890-G897

15. Takedatsu H, Mitsuyama K, Matsumoto S, Handa K, Suzuki A, Funabashi H, Okabe $\mathrm{Y}$, Hara T, Toyonaga A, Sata M: Interleukin-5 participates in the pathogenesis of ileitis in SAMP1/Yit mice. Eur J Immunol 2004, 34:1561-1569

16. Noguchi H, Kephart GM, Colby TV, Gleich GJ: Tissue eosinophilia and eosinophil degranulation in syndromes associated with fibrosis. Am J Pathol 1992, 140:521-528

17. Aceves SS, Ackerman SJ: Relationships between eosinophilic inflammation, tissue remodeling, and fibrosis in eosinophilic esophagitis Immunol Allergy Clin North Am 2009, 29:197-211, xiii-xiv

18. Rothenberg ME, Hogan SP: The eosinophil. Annu Rev Immunol 2006 24:147-174

19. Flood-Page P, Menzies-Gow A, Phipps S, Ying S, Wangoo A, Ludwig MS, Barnes N, Robinson D, Kay AB: Anti-IL-5 treatment reduces deposition of ECM proteins in the bronchial subepithelial basement membrane of mild atopic asthmatics. J Clin Invest 2003, 112:10291036

20. Chehade M, Sampson HA, Morotti RA, Magid MS: Esophageal subepithelial fibrosis in children with eosinophilic esophagitis. J Pediatr Gastroenterol Nutr 2007, 45:319-328

21. Takeda T, Hosokawa M, Takeshita S, Irino M, Higuchi K, Matsushita T, Tomita Y, Yasuhira K, Hamamoto H, Shimizu K, Ishii M, Yamamuro $\mathrm{T}$ : A new murine model of accelerated senescence. Mech Ageing Dev 1981, 17:183-194

22. Olson TS, Reuter BK, Scott KG, Morris MA, Wang XM, Hancock LN, Burcin TL, Cohn SM, Ernst PB, Cominelli F, Meddings JB, Ley K, Pizarro TT: The primary defect in experimental ileitis originates from a nonhematopoietic source. J Exp Med 2006, 203:541-552

23. Furuta GT, Turner JR, Taylor CT, Hershberg RM, Comerford K, Narravula S, Podolsky DK, Colgan SP: Hypoxia-inducible factor 1-dependent induction of intestinal trefoil factor protects barrier function during hypoxia. J Exp Med 2001, 193:1027-1034

24. Galioto AM, Hess JA, Nolan TJ, Schad GA, Lee JJ, Abraham D: Role of eosinophils and neutrophils in innate and adaptive protective immunity to larval strongyloides stercoralis in mice. Infect Immun 2006, 74:5730-5738

25. Justice JP, Borchers MT, Crosby JR, Hines EM, Shen HH, Ochkur SI, McGarry MP, Lee NA, Lee JJ: Ablation of eosinophils leads to a reduction of allergen-induced pulmonary pathology. Am J Physiol Lung Cell Mol Physiol 2003, 284:L169-L178

26. Grimaldi JC, Yu NX, Grunig G, Seymour BW, Cottrez F, Robinson DS, Hosken N, Ferlin WG, Wu X, Soto H, O'Garra A, Howard MC, Coffman 
RL: Depletion of eosinophils in mice through the use of antibodies specific for C-C chemokine receptor 3 (CCR3). J Leukoc Biol 1999, 65:846-853

27. Luster $\mathrm{AD}$, Alon $\mathrm{R}$, von Andrian $\mathrm{UH}$ : Immune cell migration in inflammation: present and future therapeutic targets. Nat Immuno 2005, 6:1182-1190

28. Jacobsen EA, Ochkur SI, Pero RS, Taranova AG, Protheroe CA, Colbert DC, Lee NA, Lee JJ: Allergic pulmonary inflammation in mice is dependent on eosinophil-induced recruitment of effector T cells. $J$ Exp Med 2008, 205:699-710

29. Cho JY, Miller M, Baek KJ, Han JW, Nayar J, Lee SY, McElwain K, McElwain S, Friedman S, Broide DH: Inhibition of airway remodeling in IL-5-deficient mice. J Clin Invest 2004, 113:551-560

30. Mishra A, Wang M, Pemmaraju VR, Collins MH, Fulkerson PC, Abonia JP, Blanchard C, Putnam PE, Rothenberg ME: Esophageal remodeling develops as a consequence of tissue specific IL-5-induced eosinophilia. Gastroenterology 2008, 134:204-214

31. Aceves SS, Newbury RO, Dohil R, Bastian JF, Broide DH: Esophageal remodeling in pediatric eosinophilic esophagitis. J Allergy Clin Immunol 2007, 119:206-212

32. Rieder F, Fiocchi C: Intestinal fibrosis in IBD-a dynamic, multifactorial process. Nat Rev Gastroenterol Hepatol 2009, 6:228-235

33. Fulkerson PC, Fischetti CA, Rothenberg ME: Eosinophils and CCR3 regulate interleukin-13 transgene-induced pulmonary remodeling. Am J Pathol 2006, 169:2117-2126

34. Pope SM, Zimmermann N, Stringer KF, Karow ML, Rothenberg ME: The eotaxin chemokines and CCR3 are fundamental regulators of allergen-induced pulmonary eosinophilia. J Immunol 2005, 175: 5341-5350

35. Humbles AA, Lloyd CM, McMillan SJ, Friend DS, Xanthou G, McKenna EE, Ghiran S, Gerard NP, Yu C, Orkin SH, Gerard C: A critical role for eosinophils in allergic airways remodeling. Science 2004, 305:1776-1779

36. Lee JJ, Dimina D, Macias MP, Ochkur SI, McGarry MP, O'Neill KR, Protheroe C, Pero R, Nguyen T, Cormier SA, Lenkiewicz E, Colbert D, Rinaldi L, Ackerman SJ, Irvin CG, Lee NA: Defining a link with asthma in mice congenitally deficient in eosinophils. Science 2004, 305: 1773-1776

37. Blyth DI, Wharton TF, Pedrick MS, Savage TJ, Sanjar S: Airway subepithelial fibrosis in a murine model of atopic asthma: suppression by dexamethasone or anti-interleukin- 5 antibody. Am J Respir Cell Mol Biol 2000, 23:241-246

38. Hamelmann E, Cieslewicz G, Schwarze J, Ishizuka T, Joetham A, Heusser C, Gelfand EW: Anti-interleukin 5 but not anti-IgE prevents airway inflammation and airway hyperresponsiveness. Am J Respir Crit Care Med 1999, 160:934-941

39. Minshall EM, Leung DY, Martin RJ, Song YL, Cameron L, Ernst $P$, Hamid Q: Eosinophil-associated TGF-beta1 mRNA expression and airways fibrosis in bronchial asthma. Am J Respir Cell Mol Biol 1997, 17:326-333

40. Tai PC, Ackerman SJ, Spry CJ, Dunnette S, Olsen EG, Gleich GJ: Deposits of eosinophil granule proteins in cardiac tissues of patients with eosinophilic endomyocardial disease. Lancet 1987, 1:643-647

41. Lintomen L, Franchi G, Nowill A, Condino-Neto A, de Nucci G, Zanesco A, Antunes E: Human eosinophil adhesion and degranulation stimulated with eotaxin and RANTES in vitro: lack of interaction with nitric oxide. BMC Pulm Med 2008, 8:13

42. Gomes I, Mathur SK, Espenshade BM, Mori Y, Varga J, Ackerman SJ: Eosinophil-fibroblast interactions induce fibroblast IL-6 secretion and extracellular matrix gene expression: implications in fibrogenesis. $J$ Allergy Clin Immunol 2005, 116:796-804

43. Schmid-Grendelmeier P, Altznauer F, Fischer B, Bizer C, Straumann A, Menz G, Blaser K, Wüthrich B, Simon HU: Eosinophils express functional IL-13 in eosinophilic inflammatory diseases. J Immunol 2002, 169:1021-1027

44. Kasaian MT, Miller DK: IL-13 as a therapeutic target for respiratory disease. Biochem Pharmacol 2008, 76:147-155

45. McKenzie GJ, Bancroft A, Grencis RK, McKenzie AN: A distinct role for interleukin-13 in Th2-cell-mediated immune responses. Curr Biol 1998, 8:339-342

46. Fichtner-Feigl S, Fuss IJ, Young CA, Watanabe T, Geissler EK, Schlitt HJ, Kitani A, Strober W: Induction of IL-13 triggers TGF-beta1-dependent tissue fibrosis in chronic 2,4,6-trinitrobenzene sulfonic acid colitis. J Immunol 2007, 178:5859-5870

47. Yu C, Cantor AB, Yang H, Browne C, Wells RA, Fujiwara Y, Orkin SH: Targeted deletion of a high-affinity GATA-binding site in the GATA-1 promoter leads to selective loss of the eosinophil lineage in vivo. $J$ Exp Med 2002, 195:1387-1395

48. Walsh ER, Thakar J, Stokes K, Huang F, Albert R, August A: Computational and experimental analysis reveals a requirement for eosinophil-derived IL-13 for the development of allergic airway responses in C57BL/6 mice. J Immunol 2011, 186:2936-2949

49. Kosiewicz MM, Nast CC, Krishnan A, Rivera-Nieves J, Moskaluk CA, Matsumoto S, Kozaiwa K, Cominelli F: Th1-type responses mediate spontaneous ileitis in a novel murine model of Crohn's disease. J Clin Invest 2001, 107:695-702 